\title{
Pantoea gaviniae sp. nov. and Pantoea calida sp. nov., isolated from infant formula and an infant formula production environment
}

\author{
Correspondence \\ Roger Stephan \\ stephanr@fsafety.uzh.ch
}

\author{
Alexandra Popp, ${ }^{1}$ Ilse Cleenwerck, ${ }^{2}$ Carol Iversen, ${ }^{3}$ Paul De Vos ${ }^{2}$ \\ and Roger Stephan ${ }^{1}$ \\ ${ }^{1}$ Institute for Food Safety and Hygiene, Vetsuisse Faculty University of Zurich, Winterthurerstrasse \\ 272, 8057 Zurich, Switzerland \\ ${ }^{2}$ BCCM/LMG Bacteria Collection, Laboratorium voor Microbiologie, Universiteit Gent, K.L. \\ Ledeganckstraat 35, 9000 Gent, Belgium \\ ${ }^{3}$ Centre for Food Safety, School of Agriculture, Food Science and Veterinary Medicine, University \\ College Dublin, Belfield, Dublin 4, Ireland
}

Over the past few years, the family Enterobacteriaceae has gained in importance for the food industry, especially for infant formula processing plants. During a recent study by us, 470 Enterobacteriaceae isolates from raw ingredients, environmental samples and products of an infant formula processing plant were investigated by biochemical tests

\section{Abbreviation: MLSA, multilocus sequence analysis.}

The GenBank/EMBL/DDBJ accession numbers for the 16S rRNA, atp $D$, gyr $B$, infB and $r p o B$ gene sequences of isolates $A 18 / 07^{\top}$ and $1400 / 07^{\top}$ are GQ367483, GQ367482, GQ367485, GQ367481 and GQ367484, and GQ367478, GQ367477, GQ367480, GQ367476 and G0367479, respectively.

A neighbour-joining dendrogram based on rpo $B$ gene sequences is available with the online version of this paper.
(API ID32E) and $r p o B$ gene sequence analysis. This technique has proven to be useful for species identification and classification in the family Enterobacteriaceae (Mollet et al., 1997; Drancourt et al., 2001; Case et al., 2007; Stephan et al., 2007, 2008). Of these 470 isolates, 65 could not be identified to species level (Popp et al., 2009). The present study deals with the further characterization of five of these isolates and shows that they represent two novel species of the genus Pantoea.

The five isolates were obtained from powdered infant formula $\left(1400 / 07^{\mathrm{T}}, \mathrm{A11} / 07, \mathrm{A18} / 07^{\mathrm{T}}\right)$ and an infant formula production environment $(484 / 07,1378 / 07)$ by using the following approach. After enrichment of the samples by incubation for $24 \mathrm{~h}$ at $37{ }^{\circ} \mathrm{C}$ in buffered peptone water, $0.1 \mathrm{ml}$ was transferred to $9 \mathrm{ml}$ Enterobacteriaceae 
enrichment broth (Becton Dickinson) and incubated for a further $24 \mathrm{~h}$ at $37^{\circ} \mathrm{C}$. The culture obtained was then plated on violet red bile glucose agar (Becton Dickinson), incubated for $24 \mathrm{~h}$ at $37{ }^{\circ} \mathrm{C}$ and the five isolates were recovered as typical red colonies.

Gram staining was done according to standard protocols. Preliminary characterization based on API ID32E analysis (bioMérieux) was performed according to the manufacturer's instructions. The results suggested that the five strains represented Pantoea spp. 1, Pantoea spp. 3 and Serratia plymuthica, but with low levels of confidence. In a next step, partial $r p o B$ gene sequences were determined following the procedure described by Mollet et al. (1997). Comparison of partial rpoB gene sequences of the new isolates amongst each other suggested that they formed two distinct groups, with $1400 / 07^{\mathrm{T}}, \mathrm{A} 11 / 07,484 / 07$ and $1378 / 07$ showing $99-100 \%$ similarity, and isolate $\mathrm{A} 18 / 07^{\mathrm{T}}$ showing $97 \%$ similarity to the other four isolates. Additional phenotypic tests (API 20E and API 50CHE; bioMérieux) were then performed, and the same two groups could be delineated based on the fermentation of galacturonate, sorbitol and potassium 5-ketogluconate, and the utilization of citrate within $24 \mathrm{~h}$ (positive for isolates $1400 / 07^{\mathrm{T}}$, A11/07, 484/07 and 1378/07; negative for $\mathrm{A} 18 / 07^{\mathrm{T}}$ ).

In the present study, the phylogenetic position of these isolates based on partial $r p o B$ gene sequences was investigated, as a multilocus sequence analysis (MLSA) scheme for the genus Pantoea according to partial atpD, gyrB, infB and $r p o B$ gene sequences was recently reported (Brady et al., 2008). By using the software package BioNumerics (Applied Maths), the $r p o B$ gene sequences of the new isolates were compared with those of reference strains of recognized Pantoea species and related taxa (Brady et al., 2008) or a newly determined sequence (Erwinia aphidicola LMG $\left.24877^{\mathrm{T}}\right)$. Phylogenetic trees were reconstructed by using the neighbour-joining (Saitou \& Nei, 1987; see Supplementary Fig. S1 in IJSEM Online), maximum-parsimony and maximum-likelihood (Felsenstein, 1985) methods. The robustness of the branches was evaluated by bootstrap resamplings of the data (Felsenstein, 1985; Supplementary Fig. S1). The maximum-parsimony and maximum-likelihood trees showed basically the same topology as the neighbour-joining tree (data not shown). The new rpoB gene sequence analysis revealed that the five isolates formed two groups closely related to several species of the genera Pantoea and Erwinia, which indicated a phylogenetic position in the genus Pantoea or the genus Erwinia.

To refine the taxonomic position of the isolates, two representatives (A18/07 $7^{\mathrm{T}}$ and $1400 / 07^{\mathrm{T}}$ ) were subjected to MLSA of concatenated partial atpD, gyrB, infB and $r p o B$ gene sequences, as Brady et al. (2008) reported that a concatenated dataset tree based on these four gene sequences is preferred over trees based on single gene sequences for species identification in the genus Pantoea. In their concatenated dataset trees, Pantoea species were supported by higher bootstrap values. Total DNA for $a t p D$, gyrB and infB gene sequence analysis was prepared according to the protocol described by Niemann et al. (1997), and partial fragments of the atpD, gyrB and infB genes were amplified and sequenced following the protocol of Brady et al. (2008), except for the gyrB gene fragment of isolate $1400 / 07^{\mathrm{T}}$, which was sequenced using the following forward and reverse primers: gyrB $07-\mathrm{F}$, gyrB 05-R (5'-TCGGAAGAAACCAGTTTGTCTT-3') and gyrB 08-R. Sequence assembly was performed by using the program AutoAssembler (Applied Biosystems), and phylogenetic analysis was performed by using the software package BioNumerics. The partial $a t p D, \operatorname{gyr} B$, infB and $r p o B$ gene sequences of the isolates were concatenated and aligned with concatenated partial $a t p D, g y r B, \inf B$ and $r p o B$ gene sequences of reference strains of Pantoea species and related taxa (Brady et al., 2008) or of Erwinia aphidicola LMG $24877^{\mathrm{T}}$. Phylogenetic trees were reconstructed by using the neighbour-joining (Saitou \& Nei, 1987; Fig. 1) and maximum-parsimony (Felsenstein, 1985) methods, and the robustness of the branches was evaluated by bootstrap resamplings of the data (Felsenstein, 1985). The maximumparsimony tree showed basically the same topology as the neighbour-joining tree and the maximum-likelihood tree by Brady et al. (2008) (data not shown). MLSA revealed that isolates $\mathrm{A} 18 / 07^{\mathrm{T}}$ and $1400 / 07^{\mathrm{T}}$ represented two novel species of the genus Pantoea, phylogenetically closely related to Pantoea septica (Brady et al., 2010). The two isolates were therefore characterized further.

The 16S rRNA genes of isolates $\mathrm{A} 18 / 07^{\mathrm{T}}$ and $1400 / 07^{\mathrm{T}}$ were amplified and sequenced as described by Franz et al. (2006), by using the primers listed by Coenye et al. (1999). Almost-complete 16S rRNA gene sequences comprising $1494 \mathrm{nt}\left(\mathrm{A} 18 / 07^{\mathrm{T}}\right)$ and $1495 \mathrm{nt}\left(1400 / 07^{\mathrm{T}}\right)$ were obtained, and compared with almost-complete 16S rRNA gene sequences of reference strains of species of the genus Pantoea and related taxa (Brady et al., 2008) or of newly determined sequences (i.e. Erwinia aphidicola LMG $24877^{\mathrm{T}}$ and Erwinia toletana LMG $24162^{\mathrm{T}}$ ). Pairwise similarities were calculated with the BioNumerics software package by using an open gap penalty of $100 \%$ and a unit gap penalty of $0 \%$. A phylogenetic tree was reconstructed by using the neighbour-joining method (Saitou \& Nei, 1987), and the robustness of the branches was evaluated by bootstrap resamplings of the data (Felsenstein, 1985; Fig. 2). Isolates $\mathrm{A} 18 / 07^{\mathrm{T}}$ and $1400 / 07^{\mathrm{T}}$ showed highest levels of $16 \mathrm{~S}$ rRNA gene sequence similarity with Pantoea deleyi LMG $24200^{\mathrm{T}}$ (98.0 and $97.9 \%$, respectively), Pantoea conspicua LMG 24534 (97.9 and 98.0\%), Pantoea brenneri LMG 5343 (97.8 and $97.9 \%$ ), Pantoea cypripedii ICMP $1591^{\mathrm{T}}$ (97.8 and 97.7\%), Erwinia toletana LMG $24162^{\mathrm{T}}$ (97.8 and $98.0 \%$ ), Erwinia tasmaniensis Et $1 / 99^{\mathrm{T}}$ (97.7\% each), P. septica LMG 5345 (97.7 and 97.5\%), Pantoea MLSA group G LMG 24248 (97.7\% each), Pantoea vagans LMG $24199^{\mathrm{T}}$ (97.7 and $97.9 \%$ ), Pantoea agglomerans NCTC $9381^{\mathrm{T}}$ (97.6 and 97.8\%), Pantoea eucalypti LMG $24197^{\mathrm{T}}$ (97.6\% each), Pantoea anthophila LMG $2558^{\mathrm{T}}$ (97.5 and $97.7 \%$ ), Pantoea ananatis ATCC $33244^{\mathrm{T}}$ (97.5 and $97.4 \%$ ), Pantoea dispersa LMG $2603^{\mathrm{T}}$ (97.4 and 97.8\%), Erwinia aphidicola LMG 


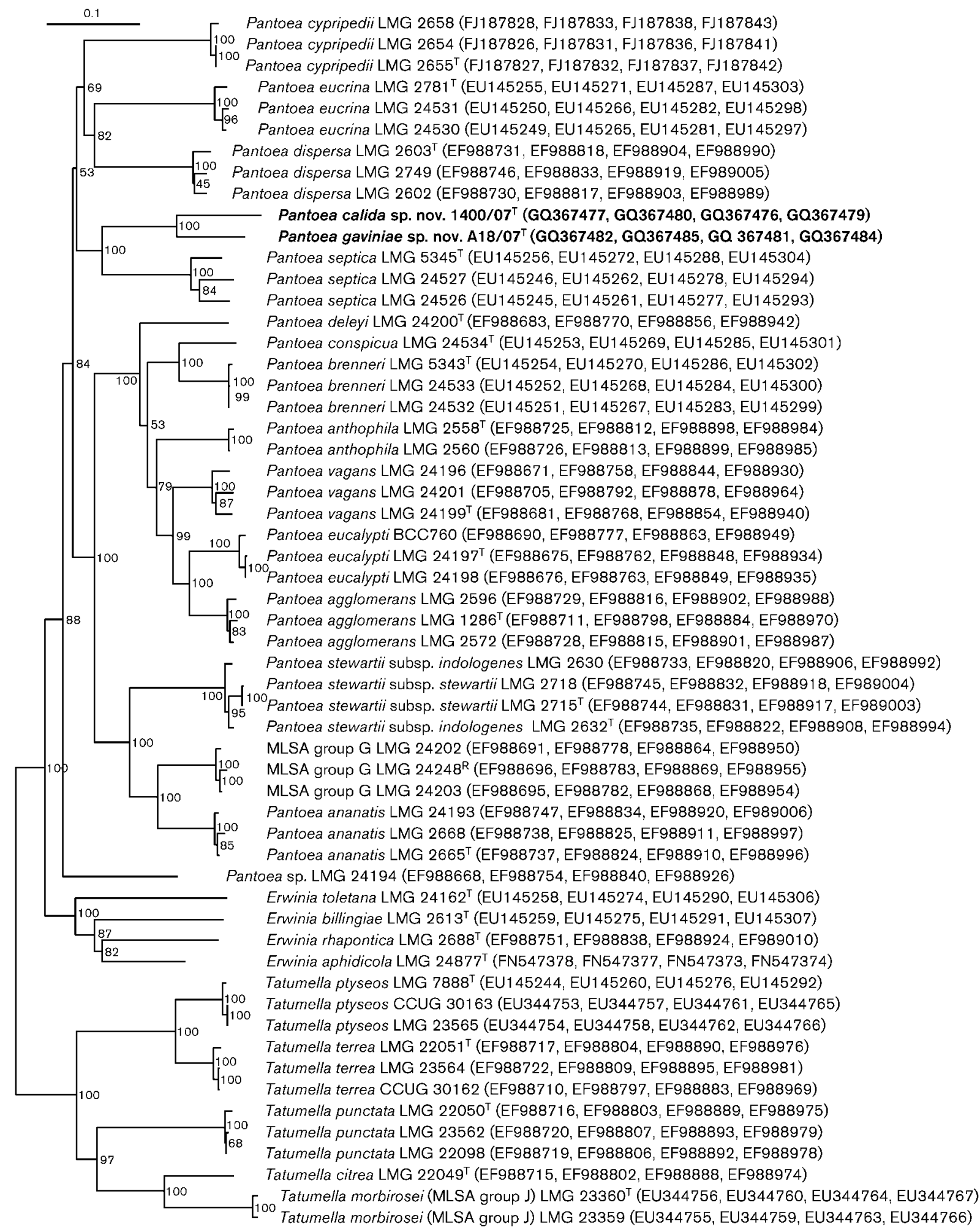

Fig. 1. Neighbour-joining dendrogram based on concatenated partial atp $D$, gyr $B$, infB and $r p o B$ gene sequences of strains $1400 / 07^{\top}$ and $A 18 / 07^{\top}$ and related taxa within the family Enterobacteriaceae. The reference strains of MLSA groups reported by Brady et al. (2008) are indicated with a superscript R. Numbers at nodes are bootstrap values (percentages of 500 replicates). Bar, 0.1 substitutions per nucleotide position. 


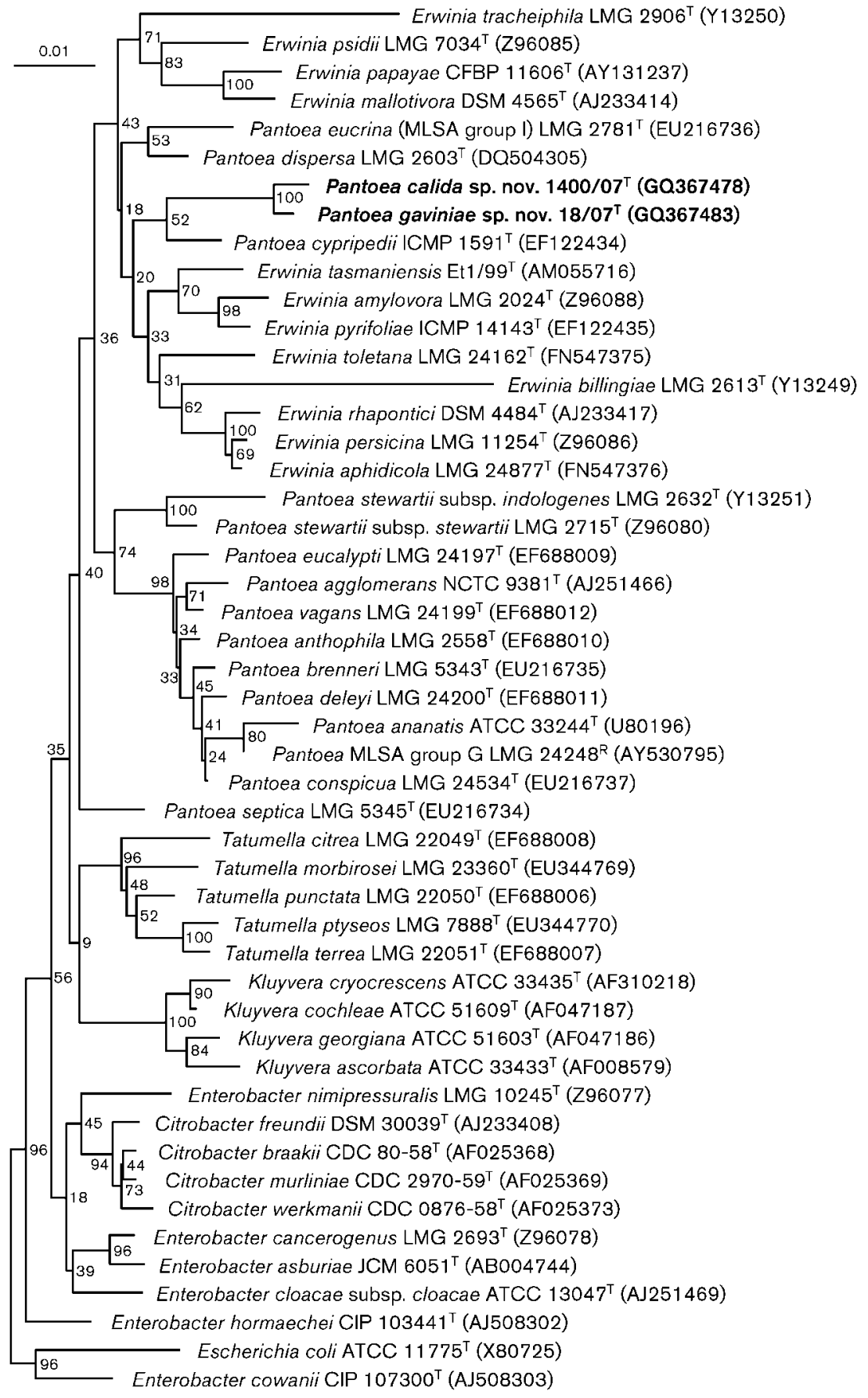

Fig. 2. Neighbour-joining dendrogram based on 16S rRNA gene sequences showing the phylogenetic relationships between strains $1400 / 07^{\top}$ and $A 18 / 07^{\top}$ and related taxa within the family Enterobacteriaceae. The reference strains of MLSA groups reported by Brady et al. (2008) are indicated with a superscript R. Numbers at nodes are bootstrap values (percentages of 1000 replicates). Bar, 0.01 substitutions per nucleotide position.
$24877^{\mathrm{T}}$ (97.4\% each), Erwinia persicina LMG $11254^{\mathrm{T}}(97.2$ and $97.3 \%)$, Enterobacter cowanii CIP $107300^{\mathrm{T}}$ (97.1 and 97.4\%), Pantoea eucrina LMG 2781 (97.1 and 97.0\%) and Pantoea stewartii subsp. stewartii LMG $2715^{\mathrm{T}}$ (97.0 and $97.2 \%)$. The level of $16 \mathrm{~S}$ rRNA gene sequence similarity between isolates $1400 / 07^{\mathrm{T}}$ and $\mathrm{A} 18 / 07^{\mathrm{T}}$ was $99.6 \%$. Levels of $16 \mathrm{~S}$ rRNA gene sequence similarity were below the range of 98.7-99\% recommended for delimiting species (Stackebrandt \& Ebers, 2006), suggesting again that the isolates represented novel species within the family Enterobacteriaceae.
As the branches representing the different genera of the Enterobacteriaceae are not monophyletic and are not supported by high bootstrap values, and as highest levels of similarity with the new isolates are found with reference strains of different genera, it can be concluded that for the Enterobacteriaceae, the similarity values obtained reflect a high level of homoplasy in the 16S rRNA gene sequences.

DNA-DNA hybridizations were performed between isolates $\mathrm{A} 18 / 07^{\mathrm{T}}$ and $1400 / 07^{\mathrm{T}}$ and the type strains of their phylogenetically closest relatives based on comparative $16 \mathrm{~S}$ 
rRNA gene sequence analysis. DNA for DNA-DNA hybridizations was prepared according to the method of Wilson (1987), with minor modifications (Cleenwerck et al., 2002), and hybridizations were carried out at $45^{\circ} \mathrm{C}$ by using a modification (Goris et al., 1998; Cleenwerck et al., 2002) of the microplate method described by Ezaki et al. (1989). Levels of DNA-DNA relatedness reported are the means $( \pm \mathrm{SD})$ of a minimum of seven hybridizations. Reciprocal reactions (i.e. $\mathrm{A} \times \mathrm{B}$ and $\mathrm{B} \times \mathrm{A}$ ) were performed and the variation between them was within the limits of this method (Goris et al., 1998). The level of DNA-DNA relatedness between isolates $1400 / 07^{\mathrm{T}}$ and $\mathrm{A} 18 / 07^{\mathrm{T}}$ was $59 \pm 4 \%$. Levels of less than $25 \%$ were found between isolate $1400 / 07^{\mathrm{T}}$ and selected reference strains: $P$. deleyi LMG $24200^{\mathrm{T}}(14 \pm 5 \%), \quad P$. conspicua LMG $24534^{\mathrm{T}}$ $(15 \pm 1 \%)$, P. brenneri LMG $5343^{\mathrm{T}}(15 \pm 6 \%)$, P. cypripedii LMG $2657^{\mathrm{T}}(14 \pm 5 \%)$, Erwinia toletana LMG $24162^{\mathrm{T}}$ $(16 \pm 14 \%)$, Erwinia tasmaniensis LMG $25318^{\mathrm{T}}(15 \pm 4 \%)$, P. septica LMG $5345^{\mathrm{T}}(23 \pm 4 \%)$, P. vagans LMG $24199^{\mathrm{T}}$ $(15 \pm 4 \%), \quad P$. agglomerans LMG $1286^{\mathrm{T}}(18 \pm 1 \%), \quad P$. eucalypti LMG $24197^{\mathrm{T}}(14 \pm 3 \%), \quad P$. ananatis LMG $2665^{\mathrm{T}}(14 \pm 0 \%), P$. dispersa LMG $2603^{\mathrm{T}}(18 \pm 13 \%), P$. eucrina LMG $2781^{\mathrm{T}}(15 \pm 7 \%)$ and $P$. stewartii subsp. stewartii LMG $2715^{\mathrm{T}}(8 \pm 6 \%)$. These values are below the $70 \%$ generally accepted for species delineation (Wayne et al., 1987), demonstrating that the two isolates represented two novel genospecies.
The DNA G + C content of isolates A18/07 ${ }^{\mathrm{T}}$ and $1400 / 07^{\mathrm{T}}$ was determined from DNA prepared in the frame of the DNA-DNA hybridization experiments, according to the HPLC method described by Mesbah et al. (1989). The values (means of three independent analyses of the same DNA sample) for $\mathrm{A} 18 / 07^{\mathrm{T}}$ and $1400 / 07^{\mathrm{T}}$ were 58.4 and $57.4 \mathrm{~mol} \%$, respectively. These values are consistent with the DNA G $+\mathrm{C}$ contents of other members of the genus Pantoea (Gavini et al., 1989; Mergaert et al., 1993; Brady et al., 2009, 2010).

The phenotypic characteristics of the five new isolates were compared with those of strains of the genus Pantoea by using various biochemical tests (API ID32E, API 20E, API 50CHE and Biotype 100 with Biotype Medium 1; bioMérieux) performed according to the manufacturer's instructions. The phenotypic characteristics of the five isolates were in accordance with the emended description of the genus Pantoea (Brady et al., 2010); however, the new isolates could be differentiated from phylogenetically related Pantoea species by their ability to ferment lactose and utilize $\beta$-gentiobiose and raffinose, their inability to ferment and utilize D-arabitol, and their inability to produce indole (Table 1). The two genospecies themselves could be differentiated, as previously mentioned, based on fermentation of galacturonate, sorbitol and potassium 5ketogluconate (Table 1). Details of the physiological and

Table 1. Differential phenotypic characteristics between Pantoea gaviniae sp. nov. and Pantoea calida sp. nov. and species of the genus Pantoea

Taxa: 1, P. gaviniae sp. nov. ( $n=1) ; 2$, P. calida sp. nov. $(n=4) ; 3$, P. brenneri; 4, P. conspicua; 5 , P. septica; 6 , P. eucrina; 7, P. cypripedii; 8 , P. vagans; 9, P. eucalypti; 10, P. deleyi; 11, P. anthophila; 12, P. agglomerans; 13, P. dispersa; 14, P. ananatis; 15, P. stewartii subsp. stewartii; 16, P. stewartii subsp. indologenes. For taxa 3-7, indole production and fermentation data are from the present study and carbon source utilization data are from Brady et al. (2010); data for taxa 8-11 from Brady et al. (2009); data for taxa 12 and 13 from Gavini et al. (1989); data for taxa 14-16 from Mergaert et al. (1993). Fermentation data (API 50CHE) were recorded after 48 h. Data for carbon source utilization tests (Biotype 100) were recorded after 4 days. - , $0-10 \%$ positive; (-), 10-20\% positive; $v, 20-80 \%$ positive; $(+)$, $80-90 \%$ positive;,$+ 90-100 \%$ positive; ND, no data available.

\begin{tabular}{|c|c|c|c|c|c|c|c|c|c|c|c|c|c|c|c|c|}
\hline Characteristic & 1 & 2 & 3 & 4 & 5 & 6 & 7 & 8 & 9 & 10 & 11 & 12 & 13 & 14 & 15 & 16 \\
\hline Indole production & - & - & - & - & - & - & - & - & - & - & - & - & - & + & - & + \\
\hline \multicolumn{17}{|l|}{ Fermentation of: } \\
\hline Potassium 2-ketogluconate & + & + & + & + & + & + & + & ND & ND & ND & $\mathrm{ND}$ & ND & ND & $(-)$ & - & $(-)$ \\
\hline D-Arabitol & - & - & - & + & + & + & - & ND & ND & + & + & ND & ND & + & - & + \\
\hline Lactose & + & + & - & + & - & - & + & + & + & ND & ND & $(-)$ & - & + & - & + \\
\hline$\beta$-Gentiobiose & + & + & + & + & - & - & - & ND & ND & + & ND & ND & ND & $\mathrm{v}$ & - & $\mathrm{V}$ \\
\hline Potassium 5-ketogluconate & - & + & - & - & - & + & + & ND & ND & ND & ND & ND & ND & $\mathrm{V}$ & - & $\mathrm{V}$ \\
\hline Melibiose & + & + & - & - & - & - & + & ND & ND & ND & ND & - & - & $(+)$ & + & + \\
\hline D-Sorbitol & - & + & - & - & - & - & - & $\mathrm{ND}$ & ND & ND & ND & - & - & $(+)$ & - & - \\
\hline Potassium gluconate & + & + & - & + & + & + & + & ND & ND & ND & ND & ND & ND & $\mathrm{ND}$ & ND & ND \\
\hline \multicolumn{17}{|l|}{ Carbon source utilization } \\
\hline$\beta$-Gentiobiose & + & + & - & + & ND & ND & + & + & - & + & - & - & + & ND & $\mathrm{ND}$ & $\mathrm{ND}$ \\
\hline 4-Aminobutyrate & - & - & $\mathrm{ND}$ & $\mathrm{ND}$ & $\mathrm{ND}$ & $\mathrm{ND}$ & $\mathrm{ND}$ & $\mathrm{ND}$ & $\mathrm{ND}$ & $\mathrm{ND}$ & $\mathrm{ND}$ & + & + & $\mathrm{ND}$ & $\mathrm{ND}$ & $\mathrm{ND}$ \\
\hline Raffinose & + & + & $\mathrm{ND}$ & - & $\mathrm{ND}$ & - & - & - & - & - & - & $\mathrm{ND}$ & - & $\mathrm{ND}$ & ND & $\mathrm{ND}$ \\
\hline$\alpha$-Ketoglutarate & + & + & ND & ND & $\mathrm{ND}$ & ND & $\mathrm{ND}$ & - & - & - & - & $\mathrm{ND}$ & $\mathrm{ND}$ & ND & $\mathrm{ND}$ & $\mathrm{ND}$ \\
\hline D-Arabitol & - & - & ND & + & $\mathrm{ND}$ & + & + & $\mathrm{ND}$ & ND & + & $\mathrm{ND}$ & $\mathrm{ND}$ & + & ND & $\mathrm{ND}$ & $\mathrm{ND}$ \\
\hline L-Tartrate & - & - & ND & + & $\mathrm{ND}$ & - & $\mathrm{ND}$ & + & + & + & - & $\mathrm{ND}$ & + & ND & $\mathrm{ND}$ & $\mathrm{ND}$ \\
\hline
\end{tabular}


biochemical characteristics of the novel species are given in the descriptions below.

The results of this polyphasic taxonomic study support the recognition of two novel species of the genus Pantoea, for which the names Pantoea gaviniae sp. nov. and Pantoea calida sp. nov. are proposed.

\section{Description of Pantoea gaviniae sp. nov.}

Pantoea gaviniae (ga.vi.ni'a.e. N.L. fem. gen. n. gaviniae of Gavini, in honour of Françoise Gavini, a French microbiologist who first described the genus Pantoea).

Cells are Gram-negative rods that are facultatively anaerobic and motile. Cells are $1.0 \mu \mathrm{m}$ wide by $2.0-3.0 \mu \mathrm{m}$ long and occur singly or in pairs. After $24 \mathrm{~h}$ of aerobic incubation at $37{ }^{\circ} \mathrm{C}$ on tripticase soy agar (TSA) medium, colonies are non-pigmented and convex. Oxidase-negative and catalasepositive. Colonies grow well at $10{ }^{\circ} \mathrm{C}$ but poorly at $7{ }^{\circ} \mathrm{C}$ (within 3 days). They grow poorly at $41.5{ }^{\circ} \mathrm{C}$ and no growth occurs at $44{ }^{\circ} \mathrm{C}$. Positive for $\beta$-glucosidase, $\beta$-galactosidase, $\alpha$-galactosidase, aesculin hydrolysis and the VogesProskauer Test, but negative for ornithine decarboxylase, arginine dihydrolase, lysine decarboxylase, urease, lipase, $\beta$ glucuronidase, $N$-acetyl- $\beta$-glucosaminidase, $\alpha$-glucosidase, $\alpha$-maltosidase, $\mathrm{L}$-aspartic acid arylamidase, tryptophan deaminase and gelatinase, and indole and $\mathrm{H}_{2} \mathrm{~S}$ production. Acid is produced under anaerobic conditions from the following compounds within $48 \mathrm{~h}$ : glycerol, L-arabinose, D-ribose, D-xylose, D-galactose, D-glucose, D-fructose, Dmannose, L-rhamnose, inositol, D-mannitol, $\mathrm{N}$-acetylglucosamine, arbutin, salicin, cellobiose, maltose, lactose, melibiose, sucrose, trehalose, raffinose, $\beta$-gentiobiose, potassium gluconate and potassium 2-ketogluconate. No acid is produced from erythritol, D-arabinose, L-xylose, adonitol, methyl $\beta$-D-xylopyranoside, L-sorbose, dulcitol, D-sorbitol, methyl $\alpha$-D-mannopyranoside, methyl $\alpha$-D-glucopyranoside, amygdalin, inulin, melezitose, starch, glycogen, xylitol, turanose, D-lyxose, D-tagatose, D-fucose, L-fucose, D-arabitol, L-arabitol, potassium 5-ketogluconate or galacturonate. Positive for utilization of $\alpha$-D-glucose, $\beta$-D-fructose, Dgalactose, trehalose, D-mannose, $\alpha$-melibiose, sucrose, raffinose, maltotriose, maltose, $\alpha$-lactose, lactulose, 1-0-methyl $\beta$-galactopyranoside, 1-0-methyl $\alpha$-galactopyranoside, cellobiose, $\beta$-gentiobiose, 1-0-methyl $\beta$-D-glucopyranoside, aesculin, D-ribose, L-arabinose, D-xylose, $\alpha$-L-rhamnose, glycerol, myo-inositol, D-mannitol, D-sorbitol, D-saccharate, mucate, L-malate, cis-aconitate, trans-aconitate, citrate, Dglucuronate, D-galacturonate, 2-keto-D-gluconate, 5-keto-Dgluconate, $\mathrm{N}$-acetyl-D-glucosamine, D-gluconate, DL-lactate, succinate, fumarate, DL-glycerate, D-glucosamine, L-aspartate, L-glutamate, L-proline, D-alanine, L-alanine, L-serine and $\alpha$-ketoglutarate within 4 days. The following compounds are not utilized as sole carbon sources within 4 days: L-sorbose, palatinose, $\alpha$-L-fucose, melezitose, D-arabitol, L-arabitol, xylitol, dulcitol, D-tagatose, maltitol, turanose, adonitol, hydroxyquinoline- $\beta$-glucuronide, D-lyxose, ierythritol, 1-0-methyl $\alpha$-D-glucopyranoside, 3-0-methyl
D-glucopyranoside, L-tartrate, D-tartrate, meso-tartrate, D-malate, tricarballylate, L-tryptophan, phenylacetate, protocatechuate, $p$-hydroxybenzoate, quinate, gentisate, $m$ hydroxybenzoate, benzoate, 3 -phenylpropionate, $m$-coumarate, trigonelline, betaine, putrescine, 4-aminobutyrate, histamine, caprate, caprylate, L-histidine, glutarate, 5aminovalerate, ethanolamine, tryptamine, itaconate, 3hydroxybutyrate, malonate, propionate and L-tyrosine. The DNA G + C content of the type strain is $58.4 \mathrm{~mol} \%$.

The type strain, A18/07 ${ }^{\mathrm{T}}\left(=\mathrm{LMG} 25382^{\mathrm{T}}=\mathrm{DSM} 22758^{\mathrm{T}}\right.$ ), was isolated from powdered infant formula.

\section{Description of Pantoea calida sp. nov.}

Pantoea calida (ca.li'da. L. fem. adj. calida warm, hot, reflecting its ability to grow at $44{ }^{\circ} \mathrm{C}$ ).

Cells are Gram-negative coccoid rods that are facultatively anaerobic and motile. Cells are $1.0 \mu \mathrm{m}$ wide by $1.5-2.0 \mu \mathrm{m}$ long and occur singly or in pairs. After $24 \mathrm{~h}$ of aerobic incubation at $37{ }^{\circ} \mathrm{C}$ on TSA medium, colonies are nonpigmented and convex. Oxidase-negative and catalasepositive. Colonies grow poorly at $10{ }^{\circ} \mathrm{C}$ (within 3 days) but well at $44{ }^{\circ} \mathrm{C}$. Positive for $\beta$-glucosidase, $\beta$-galactosidase, aesculin hydrolysis and the Voges-Proskauer test, but negative for ornithine decarboxylase, arginine dihydrolase, lysine decarboxylase, urease, lipase, $\beta$-glucuronidase, $\alpha$ maltosidase, L-aspartic acid arylamidase, tryptophan deaminase and gelatinase, and indole and $\mathrm{H}_{2} \mathrm{~S}$ production. Acid is produced under anaerobic conditions from the following compounds within $48 \mathrm{~h}$ : glycerol, L-arabinose, D-ribose, D-xylose, D-galactose, D-glucose, D-fructose, D-mannose, Lrhamnose, inositol, D-mannitol, D-sorbitol, $\mathrm{N}$-acetylglucosamine, arbutin, salicin, cellobiose, maltose, lactose, melibiose, trehalose, $\beta$-gentiobiose, potassium gluconate, potassium 2-ketogluconate, potassium 5-ketogluconate and galacturonate. No acid is produced from erythritol, D-arabinose, Lxylose, adonitol, methyl $\beta$-D-xylopyranoside, L-sorbose, dulcitol, methyl $\alpha$-D-mannopyranoside, methyl $\alpha$-D-glucopyranoside, amygdalin, inulin, melezitose, starch, glycogen, xylitol, turanose, D-lyxose, D-tagatose, D-fucose, L-fucose, Darabitol or L-arabitol. Positive for utilization of $\alpha$-D-glucose, $\beta$-D-fructose, D-galactose, trehalose, D-mannose, $\alpha$-melibiose, sucrose, raffinose, maltotriose, maltose, $\alpha$-lactose, lactulose, 1 -0-methyl $\beta$-galactopyranoside, cellobiose, $\beta$-gentiobiose, 1-0-methyl $\beta$-D-glucopyranoside, aesculin, D-ribose, L-arabinose, D-xylose, $\alpha$-L-rhamnose, glycerol, myo-inositol, Dmannitol, D-sorbitol, D-saccharate, mucate, L-malate, cis-aconitate, trans-aconitate, citrate, D-glucuronate, D-galacturonate, 2-keto-D-gluconate, 5-keto-D-gluconate, $\mathrm{N}$-acetylD-glucosamine, D-gluconate, DL-lactate, succinate, fumarate, DL-glycerate, D-glucosamine, L-aspartate, L-glutamate, Lproline, D-alanine, L-alanine, L-serine and $\alpha$-ketoglutarate within 4 days. The following compounds are not utilized as sole carbon sources within 4 days: L-sorbose, 1-0-methyl $\alpha$-galactopyranoside, palatinose, $\alpha$-L-fucose, melezitose, Darabitol, L-arabitol, xylitol, dulcitol, D-tagatose, maltitol, turanose, adonitol, hydroxyquinoline- $\beta$-glucuronide, D-lyxose, 
i-erythritol, 1-0-methyl $\alpha$-D-glucopyranoside, 3-0-methyl D-glucopyranoside, L-tartrate, D-tartrate, meso-tartrate, D-malate, tricarballylate, L-tryptophan, phenylacetate, protocatechuate, $p$-hydroxybenzoate, quinate, gentisate, $m$ hydroxybenzoate, benzoate, 3 -phenylpropionate, $m$-coumarate, trigonelline, betaine, putrescine, 4-aminobutyrate, histamine, caprate, caprylate, L-histidine, glutarate, 5-aminovalerate, ethanolamine, tryptamine, itaconate, 3-hydroxybutyrate, malonate, propionate and L-tyrosine. The DNA $\mathrm{G}+\mathrm{C}$ content of the type strain is $57.4 \mathrm{~mol} \%$.

The type strain, $1400 / 07^{\mathrm{T}}\left(=\mathrm{LMG} 25383^{\mathrm{T}}=\right.$ DSM $\left.22759^{\mathrm{T}}\right)$, was isolated from powdered infant formula. A11/07, 484/ 07 and 1378/07 are additional strains of the species.

\section{Acknowledgements}

The BCCM/LMG Bacteria Collection is supported by the Federal Public Planning Service - Science Policy, Belgium. We wish to acknowledge Katrien Vandemeulebroecke, Leentje Christiaens and Katrien Engelbeen for their technical support.

\section{References}

Brady, C., Cleenwerck, I., Venter, S., Vancanneyt, M., Swings, J. \& Coutinho, T. (2008). Phylogeny and identification of Pantoea species associated with plants, humans and the natural environment based on multilocus sequence analysis (MLSA). Syst Appl Microbiol 31, 447-460.

Brady, C. L., Venter, S. N., Cleenwerck, I., Engelbeen, K., Vancanneyt, M., Swings, J. \& Coutinho, T. A. (2009). Pantoea vagans sp. nov., Pantoea eucalypti sp. nov., Pantoea deleyi sp. nov. and Pantoea anthophila sp. nov. Int J Syst Evol Microbiol 59, 2339-2345.

Brady, C. L., Cleenwerck, I., Venter, S. N., Engelbeen, K., de Vos, P. \& Coutinho, T. A. (2010). Emended description of the genus Pantoea and description of four novel species from human clinical samples, Pantoea septica sp. nov., Pantoea eucrina sp. nov., Pantoea brenneri sp. nov. and Pantoea conspicua sp. nov., and transfer of Pectobacterium cypripedii (Hori 1911) Brenner et al. 1973 emend. Hauben et al. 1998 to the genus Pantoea emend. as Pantoea cypripedii comb. nov. Int J Syst Evol Microbiol 60, 2430-2440

Case, R. J., Boucher, Y., Dahllöf, I., Holmström, C., Doolittle, W. F. \& Kjelleberg, S. (2007). Use of $16 \mathrm{~S}$ rRNA and $r p o B$ genes as molecular markers for microbial ecology studies. Appl Environ Microbiol 73, 278-288.

Cleenwerck, I., Vandemeulebroecke, K., Janssens, D. \& Swings, J. (2002). Re-examination of the genus Acetobacter, with descriptions of Acetobacter cerevisiae sp. nov. and Acetobacter malorum sp. nov. Int $J$ Syst Evol Microbiol 52, 1551-1558.

Coenye, T., Falsen, E., Vancanneyt, M., Hoste, B., Govan, J. R. W., Kersters, K. \& Vandamme, P. (1999). Classification of Alcaligenes faecalis-like isolates from the environment and human clinical samples as Ralstonia gilardii sp. nov. Int J Syst Bacteriol 49, 405-413.

Drancourt, M., Bollet, C., Carta, A. \& Rouselier, P. (2001). Phylogenetic analyses of Klebsiella species delineate Klebsiella and Raoultella gen. nov., with description of Raoultella ornithinolytica comb. nov., Raoultella terrigena comb. nov. and Raoultella planticola comb. nov. Int J Syst Evol Microbiol 51, 925-932.

Ezaki, T., Hashimoto, Y. \& Yabuuchi, E. (1989). Fluorometric deoxyribonucleic acid-deoxyribonucleic acid hybridization in microdilution wells as an alternative to membrane filter hybridization in which radioisotopes are used to determine genetic relatedness among bacterial strains. Int J Syst Bacteriol 39, 224-229.

Felsenstein, J. (1985). Confidence limits on phylogenies: an approach using the bootstrap. Evolution 39, 783-791.

Franz, C. M. A. P., Vancanneyt, M., Vandemeulebroecke, K., De Wachter, M., Cleenwerck, I., Hoste, B., Schillinger, U., Holzapfel, W. H. \& Swings, J. (2006). Pediococcus stilesii sp. nov., isolated from maize grains. Int J Syst Evol Microbiol 56, 329-333.

Gavini, F., Mergaert, J., Beji, A., Mielcarek, C., Izard, D., Kersters, K. \& De Ley, J. (1989). Transfer of Enterobacter agglomerans (Beijerinck 1888) Ewing and Fife 1972 to Pantoea gen. nov. as Pantoea agglomerans comb. nov. and description of Pantoea dispersa sp. nov. Int J Syst Bacteriol 39, 337-345.

Goris, J., Suzuki, K., De Vos, P., Nakase, T. \& Kersters, K. (1998). Evaluation of a microplate DNA-DNA hybridization method compared with the initial renaturation method. Can J Microbiol 44, 1148-1153.

Mergaert, J., Verdonck, L. \& Kersters, K. (1993). Transfer of Erwinia ananas (synonym, Erwinia uredovora) and Erwinia stewartii to the genus Pantoea emend. as Pantoea ananas (Serrano 1928) comb. nov. and Pantoea stewartii (Smith 1898) comb. nov., respectively, and description of Pantoea stewartii subsp. indologenes subsp. nov. Int $J$ Syst Bacteriol 43, 162-173.

Mesbah, M., Premachandran, U. \& Whitman, W. B. (1989). Precise measurement of the $\mathrm{G}+\mathrm{C}$ content of deoxyribonucleic acid by highperformance liquid chromatography. Int J Syst Bacteriol 39, 159-167.

Mollet, C., Drancurt, M. \& Raoult, D. (1997). rpoB sequence analysis as a novel basis for bacterial identification. Mol Microbiol 26, 1005-1011.

Niemann, S., Puehler, A., Tichy, H. V., Simon, R. \& Selbitschka, W. (1997). Evaluation of the resolving power of three different DNA fingerprinting methods to discriminate among isolates of a natural Rhizobium meliloti population. J Appl Microbiol 82, 477-484.

Popp, A., Iversen, C., Fricker-Feer, C., Gschwend, K. \& Stephan, R. (2009). Identification of Enterobacteriaceae isolates from raw ingredients, environmental samples and products of an infant formula processing plant. Arch Lebensmittelhyg 60, 92-97.

Saitou, N. \& Nei, M. (1987). The neighbor-joining method: a new method for reconstructing phylogenetic trees. Mol Biol Evol 4, 406425.

Stackebrandt, E. \& Ebers, J. (2006). Taxonomic parameters revisited: tarnished gold standards. Microbiol Today 33, 152-155.

Stephan, R., Van Trappen, S., Cleenwerck, I., Vancanneyt, M., De Vos, P. \& Lehner, A. (2007). Enterobacter turicensis sp. nov. and Enterobacter helveticus sp. nov., isolated from fruit powder. Int J Syst Evol Microbiol 57, 820-826.

Stephan, R., Van Trappen, S., Cleenwerck, l., Iversen, C., Joosten, H., De Vos, P. \& Lehner, A. (2008). Enterobacter pulveris sp. nov., isolated from fruit powder, infant formula and infant formula production environment. Int J Syst Evol Microbiol 58, 237-241.

Wayne, L. G., Brenner, D. J., Colwell, R. R., Grimont, P. A. D., Kandler, O., Krichevsky, M. I., Moore, L. H., Moore, W. E. C., Murray, R. G. E. \& other authors (1987). International Committee on Systematic Bacteriology. Report of the ad hoc committee on reconciliation of approaches to bacterial systematics. Int J Syst Bacteriol 37, 463-464.

Wilson, K. (1987). Preparation of genomic DNA from bacteria. In Current Protocols in Molecular Biology, pp. 2.4.1-2.4.5. Edited by F. M. Ausubel, R. Brent, R. E. Kingston, D. D. Moore, J. G. Seidman, J. A. Smith \& K. Struhl. New York: Green Publishing \& Wiley. 